\title{
Adenylate Cyclase Activity in the Epididymal Adipose Tissue from Obese-Hyperglycaemic Mice
}

\author{
J.-P. Dehaye, J. Winand, and J. Christophe \\ Department of Biochemistry and Nutrition, Free University of Brussels Medical School, Brussels, Belgium
}

Summary. The adenylate cyclase activities in 1,500 $\times \mathrm{g}$ to $25,000 \times \mathrm{g}$ sediments of adipose tissue from 3 month old C57BL 6J/ob and lean mice were compared. Three anomalies were observed in obese mice: 1) a defect in basal $(-80 \%)$ and fluoridestimulated $(-50 \%)$ activities suggesting a decreased number of catalytic units per mg protein; 2) an impairment in stimulation by isoproterenol $(-85 \%)$ with no change in apparent affinity for the hormone; and, 3) no stimulatory effect of ethanol upon guanyl nucleotide-stimulated activity. The two latter effects may be due to a reduced number of $\beta$-adrenergic receptors per $\mathrm{mg}$ protein and/or to an alteration in the transducing process. On the other hand, guanyl nucleotides as well as prostaglandin $\mathrm{PGE}_{1}$ exerted similar effects in the preparations from both lean and obese adipose tissue.

Key words: obese-hyperglycaemic mice ${ }^{1}$, adipose tissue, cyclic AMP, adenylate cyclase, isoproterenol, guanyl nucleotides, prostaglandin $\mathrm{E}_{1}$, ethanol.

Lipolytic hormones act upon adipose tissue through specific plasma membrane receptors. After the coupling between each hormone and its receptor, the resulting activation of adenylate cyclase provokes a transient increase in cellular cyclic AMP. The cyclic nucleotide formed binds to the regulatory unit of protein kinase(s) allowing the free catalytic unit of this enzyme(s) to phosphorylate triglyceride lipase $[1,2]$.

1 List of abbreviations: $\mathrm{ob} / \mathrm{ob}=$ obese-hyperglycaemic; cyclic $\mathrm{AMP}=$ adenosine $3^{\prime}, 5^{\prime}$-cyclic monophosphate; $\mathrm{Gpp}(\mathrm{NH}) \mathrm{p}=$ guanyl-5'-yl imidodiphosphate; $\mathrm{PGE}_{1}=$ prostaglandin $\mathrm{E}_{1}$
Obese-hyperglycaemic mice of Bar Harbor respond poorly to the lipolytic action of isoproterenol and $\mathrm{ACTH}[3,4,5]$. This impairment is accompanied by a small increase in cyclic AMP levels in adipose tissue [5]. Thus, it can be inferred that the syndrome probably involves a defect in adipose tissue plasma membranes, either at the hormone receptor(s) level or at one or more sites of the adenylate cyclase system. Our purpose in this work was to locate this defect more precisely. Indeed, reports on adenylate cyclase activity in adipose tissue from obesehyperglycaemic mice are rare, conflicting $[6,7,8]$, and only one of them is well documented [8]. We have therefore studied the action of isoproterenol on adenylate cyclase, the integrity of the catalytic and of the regulatory units and the interaction between these components. A preliminary account has appeared [9].

\section{Materials and Methods}

\section{A. Preparation of Adipose Tissue Extracts}

Our colony of lean C57BL $6 \mathrm{~J}+1+$ mice and ob/ob obese mice was started with animals purchased from the Jackson Memorial Laboratories (Bar Harbor, Maine, USA). The animals were fed ad libitum on a standard chow (U.A.R., Villemoisson, France) and were sacrificed at the age of three months. In each experiment, six lean and two obese mice were killed by a blow on the neck. The epididymal adipose tissue was quickly removed and deep-frozen at $-70^{\circ} \mathrm{C}$ in $2 \mathrm{ml} 0.25 \mathrm{~mol} / 1$ sucrose. After a 10 second ultrasonication at $0^{\circ} \mathrm{C}$ with a MSE Sonifier (amplitude 3 , high power), the homogenate was centrifuged for 10 minutes at $1,500 \times \mathrm{g}$. The fat cake and the pellet were discarded and the internatant was centrifuged for $15 \mathrm{~min}$ at $25,000 \times \mathrm{g}$. The pellet was resuspended in $1 \mathrm{mmol} / 1 \mathrm{KHCO}_{3}$ to a concentration of $2 \mathrm{mg}$ protein $/ \mathrm{ml}$ and used immediately for adenylate cyclase assays.

\section{B. Adenylate Cyclase Assay}

Unless stated otherwise, $10 \mu \mathrm{l}$ aliquots of the resuspended 1,500 $\times \mathrm{g}$ to $25,000 \times \mathrm{g}$ pellet were tested at $37^{\circ} \mathrm{C}$ for adenylate cyclase 


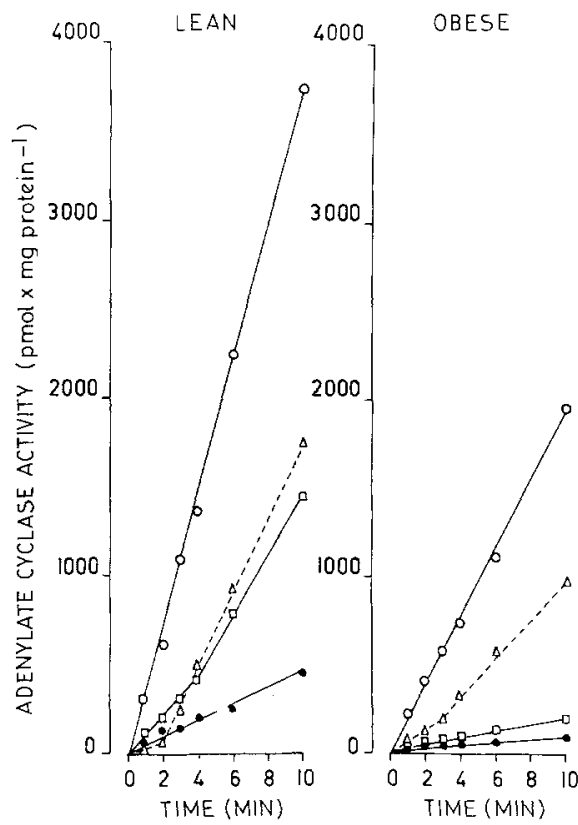

Fig. 1. Effects of $\mathrm{NaF}, \mathrm{Gpp}(\mathrm{NH}) \mathrm{p}$ and isoproterenol on the kinetics of adenylate cyclase activity in $1,500 \times \mathrm{g}$ to $25,000 \times \mathrm{g}$ pellets of adipose tissue homogenates from lean and ob/ob mice. Stimulated activities were recorded in the presence of $10 \mathrm{mmol} / 1$ $\mathrm{NaF}(\mathrm{O}-\mathrm{O}), 10^{-5} \mathrm{~mol} / \mathrm{l} \mathrm{Gpp}(\mathrm{NH}) \mathrm{p}(\triangle---\triangle)$, and $10^{-4} \mathrm{~mol} / \mathrm{l}$ isoproterenol $(\square-\square)$ and were compared to basal activities (-) tested as detailed in the Materials and Methods section. Results are the means of experiments made in duplicate with three different enzyme preparations

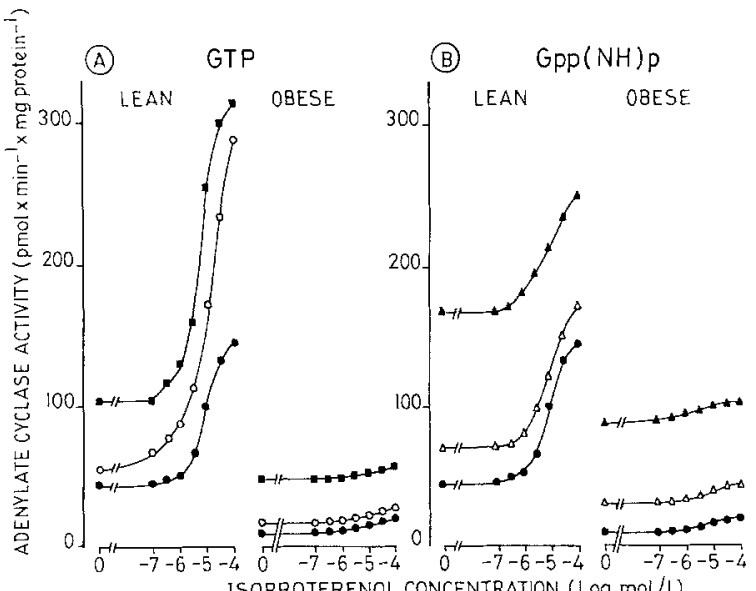

Fig. 2. Dose-response curves of adenylate cyclase activity in 1,500 $\times \mathrm{g}$ to $25,000 \times \mathrm{g}$ pellets of adipose tissue homogenates from lean and ob/ob mice, stimulated by increasing concentrations of isoproterenol (- These dose-response curves were also recorded in the presence of $3 \times 10^{-7} \mathrm{~mol} / \mathrm{I} \mathrm{GTP}(\mathrm{O}-\mathrm{O})$ and 3 $\times 10^{-5} \mathrm{~mol} / \mathrm{l}$ GTP (—- A left panel); and $10^{-7} \mathrm{~mol} / \mathrm{l}$ $\mathrm{Gpp}(\mathrm{NH}) \mathrm{p}(\triangle-\triangle)$ and $10^{-5} \mathrm{~mol} / \mathrm{l} \mathrm{Gpp}(\mathrm{NH}) \mathrm{p}(\boldsymbol{\Lambda}-\mathbf{\Delta})(\mathrm{B}$ right panel). All reactions were stopped after 10 min. Mean of 3 experiments made in duplicate activity. The total incubation volume of $60 \mu \mathrm{l}$ contained $0.5 \mathrm{~m}$ $\mathrm{mol} / 1\left[\alpha_{-}{ }^{32} \mathrm{P}\right]$ ATP $(1 \mu \mathrm{Ci}), 5 \mathrm{mmol} / 1 \mathrm{MgCl}_{2}, 0.5 \mathrm{mmol} / \mathrm{l}$ EGTA, $1 \mathrm{mmol} / 1$ theophylline, $1 \mathrm{mmol} / 1$ cyclic AMP, $30 \mathrm{mmol} / 1$ tris- $\mathrm{HC}$ (pH 7.4), and an ATP-regenerating system $(7.5 \mathrm{mmol} / 1$ phosphoenolpyruvate and $25 \mathrm{U} / \mathrm{ml}$ pyruvate kinase). The reaction was stopped with $0.5 \mathrm{ml}$ of an ice-cold solution containing $1 \mathrm{mmol} / \mathrm{l}$ cyclic $\left[8-{ }^{3} \mathrm{H}\right]$ AMP $(0.1 \mu \mathrm{Ci}), 2 \mathrm{mmol} / 1 \mathrm{ATP}$ and $0.1 \%$ sodium dodecylsulphate. Cyclic $\left[{ }^{32} \mathrm{P}\right]$ AMP formed and cyclic $\left[8-{ }^{3} \mathrm{H}\right]$ AMP added to monitor the recovery were then isolated essentially according to the method of Salomon et al. [10]. The Dowex $50 \mathrm{~W}-$ $\mathrm{X} 4$ column, with a three $\mathrm{ml}$ bed volume, was eluted with $5 \mathrm{ml}$ distilled water over $0.2 \mathrm{ml} 1.5 \mathrm{~mol} / 1$ imidazole buffer ( $\mathrm{pH} 7.2$ ) The recovery of cyclic AMP was $80 \%$. The second column was made with $1 \mathrm{~g}$ of alumina oxide and eluted with $0.1 \mathrm{~mol} / \mathrm{l}$ imidazole buffer ( $\mathrm{pH} 7.2$ ). This resulted in an overall recovery of cyclic AMP of about $60 \%$. The eluates from the alumina columns were collected in scintillation vials containing $12 \mathrm{ml}$ Instagel (Packard Instrument Co, Downers Grove, USA). $\left[{ }^{32} \mathrm{P}\right]$ and $\left[{ }^{3} \mathrm{H}\right]$ were counted in a Packard 2450 Tri-Carb liquid scintillation spectrometer. With this method, duplicate determinations agreed within $5 \%$. Unless stated otherwise, the incubations were stopped after $10 \mathrm{~min}$. The points on the graphs represent the means of experiments conducted with three different preparations used to ascertain reproducibility.

Protein was detemined by the method of Lowry et al. [11], using bovine serum albumin (Fraction V) as standard.

\section{Materials}

Cyclic $\left[8-{ }^{3} \mathrm{H}\right]$ AMP $(27 \mathrm{Ci} / \mathrm{mmol})$ and $\left[\alpha^{-32} \mathrm{P}\right]$ ATP $(1$ to $10 \mathrm{Ci} /$ mmol) were obtained from the Radiochemical Centre (Amersham, England). Phosphoenolpyruvate trisodium salt, ATP disodium salt (low calcium content from equine muscle, 99-100\%), cyclic AMP, and isoproterenol were purchased from Sigma Chemical Co. (St. Louis, USA). Bovine albumin (Pentex, Fraction V, fatty acid poor) was from Miles Lab. (Kankakee, USA) and Dowex $50 \mathrm{~W}-\mathrm{X} 4$ (100-200 mesh $\mathrm{H}^{+}$form) from Serva (Heidelberg, Germany). Protaglandin PGE $_{1}$ was a gift from Dr. D. A. van Dorp (Unilever, Vlaardigen, The Netherlands). All other reagents were commercial preparations of analytical grade.

\section{Results}

The basal activity of the adenylate cyclase preparations from adipose tissue of lean mice was linear for at least 10 minutes (Fig. 1). Isoproterenol at a $10^{-4} \mathrm{~mol} / 1$ concentration stimulated this activity threefold. The guanyl nucleotide $\mathrm{Gpp}(\mathrm{NH}) \mathrm{p}$, at a $10^{-5} \mathrm{~mol} / 1$ concentration, proved to be more effective since a four-fold increase over basal activity was obtained after $10 \mathrm{~min}$, in spite of the $2 \mathrm{~min}$ lag period which preceded activation. Finally, $10^{-2} \mathrm{~mol} / \mathrm{l}$ fluoride evoked the highest activation of the enzyme, i. e. a ten-fold increase over control values.

In obese mice, the basal activity was also linear for at least 10 minutes but per mg protein was only $20 \%$ of that of lean controls (Fig. 1). In the presence of $10^{-4} \mathrm{~mol} / \mathrm{l}$ isoproterenol, the activity of the enzyme only doubled. On the other hand, both $\mathrm{Gpp}(\mathrm{NH}) \mathrm{p}$ and fluoride proved to be highly effective 
in obese animals, increasing cyclic AMP production 12- and 23-fold respectively (Fig. 1).

\section{A. Activation by Isoproterenol}

From dose-response curves with isoproterenol, it appears that in lean mice, threshold, half-maximal and maximal observed effects occurred at approximately $3 \times 10^{-7} \mathrm{~mol} / 1,10^{-5} \mathrm{~mol} / 1$ and $10^{-4} \mathrm{~mol} / 1$ (Fig. 2). With obese animals, similar effects were observed with the same concentrations but the activity obtained in the presence of $10^{-4} \mathrm{~mol} / 1$ isoproterenol was only $15 \%$ of that of the lean preparations (Fig. 2).

\section{B. Acitvation by Guanyl Nucleotides}

Half-maximal stimulation with GTP and Gpp(NH)p occurred at $3 \times 10^{-6} \mathrm{~mol} / \mathrm{l}$ and $10^{-6} \mathrm{~mol} / 1$ respectively. Maximal effects of $\mathrm{Gpp}(\mathrm{NH}) \mathrm{p}$ were twice as high as those of GTP (Fig. 3).

In obese mice, the concentrations of each nucleotide giving half-maximal effects were approximately the same as in lean mice, but the magnitude of maximal effects was only $50 \%$ when compared to lean controls (Fig. 3).

\section{Interactions between Isoproterenol and Guanyl Nucleotides}

Figure 4 illustrates time-studies performed in the presence of $10^{-5} \mathrm{~mol} / 1$ GTP or Gpp(NH)p, used alone or in combination with $10^{-4} \mathrm{~mol} / 1$ isoproterenol.

In adipose tissue from both groups of mice, the 2-4 min lag period preceding the activation by GTP or $\mathrm{Gpp}(\mathrm{NH}) \mathrm{p}$ alone disappeared when the hormone was also present (Fig. 4).

The interaction between increasing concentrations of isoproterenol and both guanyl nucleotides was also studied (Fig. 2). GTP and Gpp(NH)p did not change the apparent affinity for the hormone. When isoproterenol at a $10^{-4} \mathrm{~mol} / 1$ concentration was used in combination with guanyl nucleotides, the effects usually obtained were additive except in one case: when isoproterenol was offered in combination with GTP to plasma membranes from lean mice, a slight potentiation became apparent (Fig. 2).

\section{Effect of Fluoride}

In adipose tissue from both groups of mice, half-maximal and maximal stimulations occurred respectively at $5 \mathrm{mmol} / \mathrm{l}$ and $10 \mathrm{mmol} / \mathrm{l}$. Maximal effects corre-

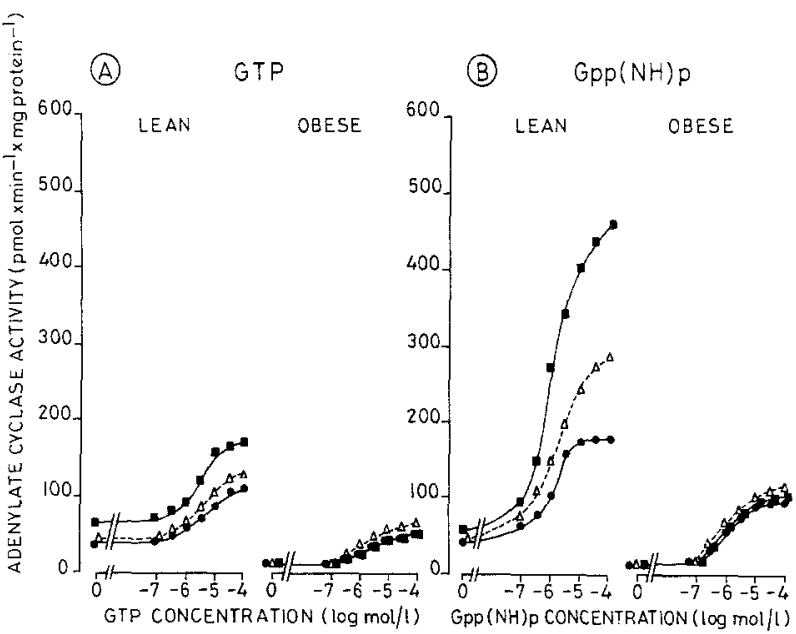

Fig. 3. Dose-response curves of adenylate cyclase activity in 1,500 $\times \mathrm{g}$ to $25,000 \times \mathrm{g}$ pellets of adipose tissue homogenates from lean and ob/ob mice in the presence of increasing concentrations of GTP (left panel A) or Gpp(NH)p (right panel B) tested in the absence (-) and in the presence of prostaglandin $P_{-} G_{1}$ $(10 \mu \mathrm{g} / \mathrm{ml}: \triangle---\triangle)$ or $0.86 \mathrm{~mol} / 1$ ethanol (שbation conditions as in Fig. 1. The reaction was stopped after $10 \mathrm{~min}$. Mean of 3 experiments made in duplicate. (N.B.: Figure $5 \mathrm{~B}$ shows that the low $0.05 \mathrm{~mol} / \mathrm{l}$ final ethanol concentration needed to dissolve prostaglandin $\mathrm{PGE}_{1}$ was without effect per se on adenylate cyclase)

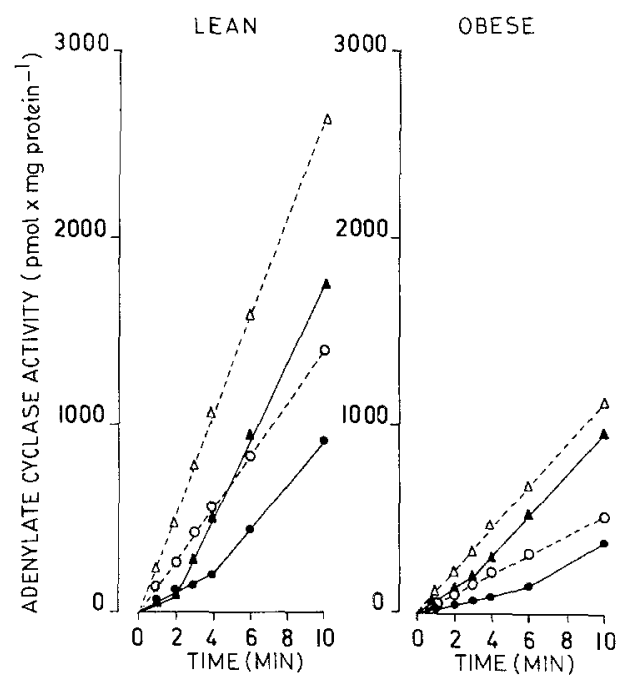

Fig. 4. Effects of guanyl nucleotides with or without isoproterenol on the kinetics of adenylate cyclase activity in $1,500 \times \mathrm{g}$ to 25,000 $\times \mathrm{g}$ pellets of adipose tissue homogenates from lean and ob/ob mice. The enzyme was assayed with $10^{-5} \mathrm{~mol} / \mathrm{l}$ GTP ($10^{-5} \mathrm{~mol} / \mathrm{l}$ GTP combined with $10^{-4} \mathrm{~mol} / \mathrm{l}$ isoproterenol $(\mathrm{O}-\mathrm{O}), 10^{-5} \mathrm{~mol} / \mathrm{l} \mathrm{Gpp}(\mathrm{NH}) \mathrm{p}(\boldsymbol{\Lambda}-\mathbf{\Lambda})$, and $10^{-5} \mathrm{~mol} / \mathrm{l}$ $\mathrm{Gpp}(\mathrm{NH}) \mathrm{p}$ combined with $10^{-4} \mathrm{~mol} / \mathrm{l}$ isoproterenol $(\triangle---\triangle)$. The incubation medium is described in Fig. 1. Mean of 3 experiments made in duplicate 

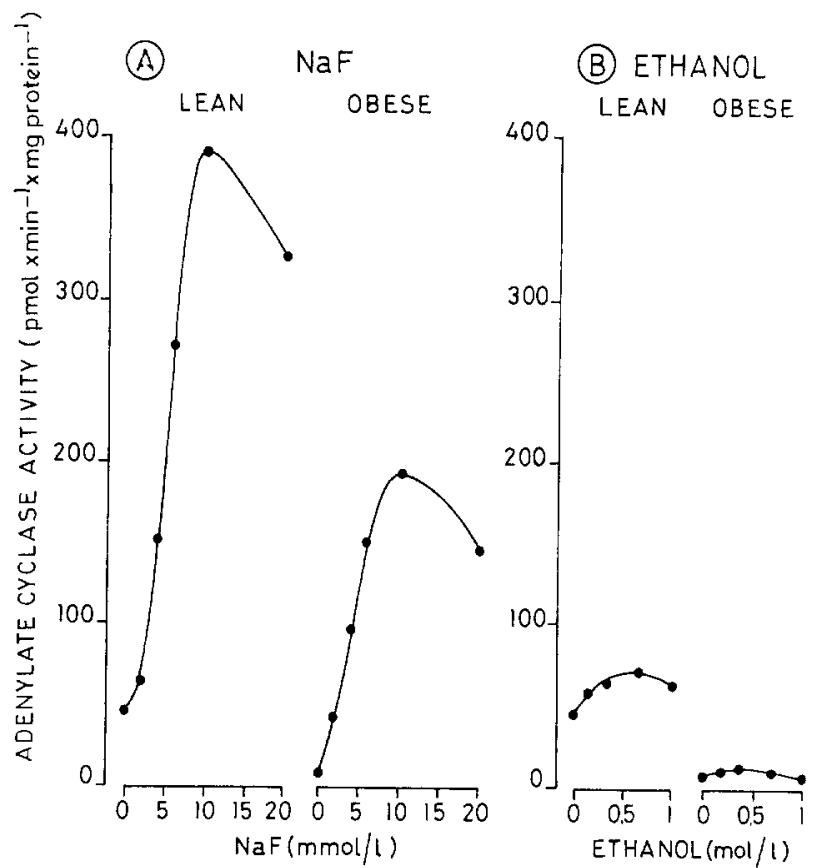

Fig. 5. Effects of increasing concentrations of $\mathrm{NaF} A$ or ethanol $\mathbf{B}$ on adenylate cyclase activity in $1,500 \times \mathrm{g}$ to $25,000 \times \mathrm{g}$ pellets of adipose tissue homogenates from lean and ob/ob mice. Same incubation conditions as in Figure 1. The reaction was stopped after $10 \mathrm{~min}$. Mean of 3 experiments made in duplicate

Table 1. Adenylate cyclase activity of a $1,500 \times \mathrm{g}$ to $25,000 \times \mathrm{g}$ pellet of epididymal adipose tissue from obese and lean mice. Effects of $\mathrm{NaF}$, isoproterenol, guanyl nucleotides, ethanol and prostaglandin $\mathrm{PGE}_{1}$. The incubation time was $10 \mathrm{~min}$. Results are means \pm SEM for 8 experiments

\begin{tabular}{|c|c|c|}
\hline \multirow[t]{2}{*}{ Additions } & \multicolumn{2}{|c|}{$\begin{array}{l}\text { pmol cyclic AMP } \times \mathrm{mg} \\
\text { protein }^{-1} \times \min ^{-1}\end{array}$} \\
\hline & Lean mice & ob/ob mice \\
\hline None & $42 \pm 5$ & $8 \pm 3$ \\
\hline $5 \times 10^{-3} \mathrm{~mol} / \mathrm{l} \mathrm{NaF}$ & $216 \pm 30$ & $142 \pm 20$ \\
\hline $10^{-2} \mathrm{~mol} / 1 \mathrm{NaF}$ & $392 \pm 18$ & $194 \pm 16$ \\
\hline $10^{-4} \mathrm{~mol} / 1$ isoproterenol & $145 \pm 15$ & $18 \pm 3$ \\
\hline $10^{-5} \mathrm{~mol} / \mathrm{l} \mathrm{GTP}$ & $93 \pm 9$ & $40 \pm 13$ \\
\hline $10^{-5} \mathrm{~mol} / 1 \mathrm{Gpp}(\mathrm{NH}) \mathrm{p}$ & $174 \pm 15$ & $97 \pm 9$ \\
\hline $\begin{array}{l}5 \times 10^{-3} \mathrm{~mol} / 1 \mathrm{NaF}+10^{-4} \\
\mathrm{~mol} / 1 \text { isoproterenol }\end{array}$ & $324 \pm 40$ & $174 \pm 19$ \\
\hline $\begin{array}{l}5 \times 10^{-3} \mathrm{~mol} / 1 \mathrm{NaF}+10^{-5} \\
\mathrm{~mol} / 1 \mathrm{GTP}\end{array}$ & $267 \pm 30$ & $173 \pm 20$ \\
\hline $\begin{array}{l}5 \times 10^{-3} \mathrm{~mol} / 1 \mathrm{NaF}+10^{-5} \\
\mathrm{~mol} / \mathrm{l} \mathrm{Gpp}(\mathrm{NH}) \mathrm{p}\end{array}$ & $363 \pm 43$ & $194 \pm 20$ \\
\hline $0.86 \mathrm{~mol} / 1$ ethanol & $69 \pm 10$ & $8 \pm 4$ \\
\hline $\begin{array}{l}0.86 \mathrm{~mol} / \mathrm{l} \text { ethanol }+10^{-4} \\
\mathrm{~mol} / \mathrm{l} \text { isoproterenol }\end{array}$ & $151 \pm 10$ & $20 \pm 3$ \\
\hline $\begin{array}{l}0.86 \mathrm{~mol} / \mathrm{l} \text { ethanol }+5 \times 10^{-3} \\
\mathrm{~mol} / \mathrm{l} \mathrm{NaF}\end{array}$ & $613 \pm 55$ & $254 \pm 28$ \\
\hline $\begin{array}{l}\mathrm{PGE}_{1}(10 \mu \mathrm{g} / \mathrm{ml}) \\
\mathrm{PGE}_{1}(10 \mu \mathrm{g} / \mathrm{ml})+10^{-4}\end{array}$ & $42 \pm 4$ & $8 \pm 3$ \\
\hline $\begin{array}{l}\mathrm{PGE}_{1}(10 \mu \mathrm{g} / \mathrm{ml})+10^{-4} \\
\mathrm{~mol}^{\prime} / \mathrm{l} \text { isoproterenol } \\
\mathrm{PGE}_{1}(10 \mu \mathrm{g} / \mathrm{ml})+5 \times 10^{-3}\end{array}$ & $135 \pm 15$ & $202 \pm 25$ \\
\hline $\mathrm{mol} / \mathrm{l} \mathrm{NaF}$ & $277 \pm 35$ & $202 \pm 25$ \\
\hline
\end{tabular}

sponded to 10-fold increases in adipose tissue from normal mice and 23 -fold increases in adipose tissue from obese mice. A concentration higher than $10 \mathrm{mmol} / \mathrm{l}$ gave a reproducible "toxic" effect (Fig. 5).

Fluoride was tested at $5 \mathrm{mmol} / 1$ (i. e. at half-maximal concentration) in the presence of $10^{-4} \mathrm{~mol} / \mathrm{l}$ isoproterenol, $10^{-5} \mathrm{~mol} / 1 \mathrm{Gpp}(\mathrm{NH}) \mathrm{p}$, or $10^{-5} \mathrm{~mol} / \mathrm{l}$ GTP. Under these conditions, the effects were mostly additive and, in the first two situations, they approached the maximal effects obtained with $10 \mathrm{mmol} / \mathrm{l} \mathrm{NaF}$ alone (Table 1 ).

\section{E. Effects of Ethanol}

Dose-response curves for ethanol have been performed (Fig. 5). A maximal 57\% activation of adenylate cyclase was obtained with $0.69 \mathrm{~mol} / 1$ ethanol in lean mice. With $1.03 \mathrm{~mol} / \mathrm{l}$ ethanol, this effect was significantly reversed ( $+39 \%$ only). In obese mice, only a moderate activation was observed at 0.34 $\mathrm{mol} / 1 \mathrm{ethanol}$, and at $1.03 \mathrm{~mol} / \mathrm{l}$ ethanol, the basal activity was recovered.

Ethanol greatly enhanced the $5 \mathrm{mmol} / 1$ fluoride activation in both animals, giving the highest activities of the enzyme recorded in these experiments (Table 1). This effect was proportionately greater in lean $(+184 \%)$ than in obese $(+79 \%)$ animals. The discrepancy between obese and lean mice was even more striking in the presence of guanyl nucleotides: ethanol at a $0.86 \mathrm{~mol} / 1$ concentration potentiated the action of either GTP or $\mathrm{Gpp}(\mathrm{NH}) \mathrm{p}$ in lean but not in obese mice (Fig. 3). Finally, in both lean and ob/ob mouse adipose tissue "membranes", ethanol was ineffective when isoproterenol was used (Table 1).

\section{F. Effects of Prostaglandin $P G E_{1}$}

In adipose tissue of both groups of mice, prostaglandin PGE $_{1}$ exerted no effect on basal- as well as on isoproterenol-stimulated activities (Table 1). On the other hand, $\mathrm{PGE}_{1}$ moderately potentiated the action of both guanyl nucleotides (Fig. 3) and of fluoride (Table 1).

\section{Discussion}

The obese-hyperglycaemic syndrome is a classical triad characterised by obesity, hyperinsulinaemia and insulin resistance [12]. This has been correlated with a reduced number of insulin receptors in adipose tissue and liver plasma membranes [13]. In addition, hormone-induced lipolysis is impaired in adipose tissue $[3,4,5]$ and the accompanying elevation of cyclic 
AMP is sharply curtailed [5]. This anomaly of the adenylate cyclase system may therefore represent a second plasma membrane defect. The question then arises whether the syndrome might implicate a more general alteration of adipocyte plasma membranes as already suggested for the liver plasmalemma [14].

The basal specific activity of adenylate cyclase in the adipose tissue from obese mice was only $20 \%$ of that from lean controls (Table 1 and Fig. 1). This is a sharper difference than the two-fold reduction previously reported by Enser [6] in crude homogenates. The present data are even more at variance with those of Laudat and Pairault [8] who observed the same basal activity in a plasma membrane preparation purified from isolated adipocytes of lean and obese mice [15]. However, Chang et al. [14] and Abraham and Beloff-Chain [16] observed that the isolation of adipocytes from ob/ob mice selectively destroys large cells. Thus, it might well be that Laudat and Pairault [15] worked on a preparation of membranes from selected small cells. In our experiments also, it cannot be excluded a priori that the preparation technique could have selected membrane material disproportionately. Comparing the group of lean to that of obese mice, our homogenisation technique allowed a similar recovery of protein in the $1,500 \times \mathrm{g}$ to $15,000 \times \mathrm{g}$ pellets $(2.7 \pm 0.8 \%$ of total protein in lean mice, vs $2.4 \pm 0.7 \%$ of total protein in obese mice, mean values \pm SEM of 6 experiments). This procedure increased the basal specific activity of adenylate cyclase (in pmol cyclic AMP mg protein ${ }^{-1} \times$ min $^{-1}$ ) from $11 \pm 3$ in crude homogenates to $42 \pm 5$ in the final adipose tissue pellets from lean mice, and from $2 \pm 1$ to $8 \pm 3$ in similar preparations from obese animals. Since the obese adipose tissue contained $0.67 \pm 0.08 \mathrm{mg}$ total protein $/ 100 \mathrm{mg}$ wet weight as compared to $1.28 \pm$ $0.10 \mathrm{mg}$ total protein $/ 100 \mathrm{mg}$ wet weight in lean mice, an absolute decrease of basal adenylate cyclase activity on a wet weight and on a protein basis appears evident in the adipose tissue of obese mice.

Fluoride is believed to act directly upon the catalytic unit of the enzyme in rat adipose tissue [17]. In both mice, the $5 \mathrm{mmol} / 1$ half-maximal stimulatory concentration of fluoride closely compared with that having similar effects in rats [18]. Fluoride at halfmaximal concentration gave additive effects in the presence of isoproterenol or a guanyl nucleotide (Table 1). This suggests that the anion acted independently of the hormone receptor and the regulatory unit. Maximal activities were two-fold lower in obese mice than in lean animals per mg protein. This is a good indication of reduced enzyme concentration in the adipose tissue plasma membrane from obese mice.
The most important activation of adenylate cyclase over basal activity in the presence of isoproterenol was 13 times lower in obese mice than in lean controls, and represented only $9 \%$ of the fluoridestimulated activity as compared to $37 \%$ of the corresponding value in lean animals. However, the apparent hormone sensitivity was the same in both animals (Figs. 1 and 2). These results agree with those of Laudat and Pairault [8] and can be correlated with the low increase in cyclic AMP levels observed in fragments of obese adipose tissue during hormonal stimulation [5]. They also suggest that activation of adenylate cyclase by isoproterenol was impaired.

In rats, insulin added in vitro has been reported to inhibit the catecholamine-ACTH and/or glucagonstimulated adenylatecyclase activity in crude membrane fractions from adipose tissue and liver [19]. In obese-hyperglycaemic mice, we found that the basal and glucagon-sensitive adenylatecyclase activity from partially purified hepatic plasma membranes was normal (to be published). Therefore, it is unlikely that the chronic hyperinsulinism prevailing in vivo in obese mice was responsible for the reduced adenylate cyclase activity observed in adipose tissue unless the plasma membranes from adipose tissue and liver were diversely regulated by insulin.

The low isoproterenol response of adipose tissue of obese mice might thus reflect either a decreased number of hormone receptors with normal affinity, or inadequate hormone stimulation. Laudat et al. [20] have shown that adipocyte plasma membranes from obese mice bind only $65-70 \%{ }^{3} \mathrm{H}$-epinephrine, when compared to lean controls. We planned to test partially the second hypothesis, i. e. the efficiency of the regulatory unit, using GTP and $\operatorname{Gpp}(\mathrm{NH}) \mathrm{p}$. Indeed, the general scheme advocated by Rodbell et al. [21] implies that hormones activate adenylate cyclase by converting the regulatory subunit into a reversible acceptor of guanyl nucleotides. Besides, it has been reported that these nucleotides could even reveal a "latent" response to the hormone [22].

In both mice, when used alone, Gpp(NH)p was more efficient than GTP in terms of $\mathrm{Km}_{\text {app }}$ and $\mathrm{V}_{\text {max }}$ (Fig. 3 and Table 1). Besides, the lag-phase observed with Gpp(NH)p (Fig. 1) was shorter than with GTP. This was probably due to a slower hydrolysis [23] and/or to a faster reaction of $\mathrm{Gpp}(\mathrm{NH}) \mathrm{p}$ with the catalytic unit. In both mice, in the presence of isoproterenol, the lag-phase observed with $\mathrm{Gpp}(\mathrm{NH}) \mathrm{p}$ disappeared. Both GTP and Gpp(NH)p were unable to modify the apparent affinity for the hormone. Nevertheless, while in lean mice, GTP was able to potentiate the effects of isoproterenol, as shown by the fact that $V_{\max }$ values were now as high as those obtained with $10 \mathrm{mmol} / 1$ fluoride, in obese mice, this 
effect was absent (Fig. 5 and Table 1). Thus, with respect to the $\beta$-adrenergic receptor, it can be concluded that the coupling between the hormone receptor and the catalytic unit via the regulatory unit, and/ or the number of hormone binding sites are defective in obese-hyperglycaemic mice.

Gorman and Bitensky [24] reported that shortchain alcohols can reversibly activate basal- and glucagon-, but not epinephrine-sensitive adenylate cyclase activities in the liver. In adipose tissue from lean mice, ethanol enhanced the basal-, guanyl nucleotide- and fluoride-stimulated activities. However, the activation by isoproterenol was not modified, confirming that $\beta$-adrenergic receptors are insensitive to ethanol (Figs. 3 and 5, Table 1).

In obese mice, ethanol slightly potentiated the action of fluoride but inhibited the activation by $\mathrm{Gpp}(\mathrm{NH}) \mathrm{p}$ and could not influence the activation by GTP (Fig. 3). This might suggest that the guanyl nucleotide site itself or its coupling with the catalytic unit could not be disturbed as easily in obese as in non-obese animals by ethanol. In this respect, and considering that phospholipids are involved in the process transducing signals in the plasma membrane [25], it would be worth studying the lipid composition of the adipocyte plasma membrane from obese mice.

In both mice, $\mathrm{PGE}_{1}$ was unable to activate basal and isoproterenol-stimulated activities. However, $\mathrm{PGE}_{1}$ moderately potentiated the effects of high concentrations of GTP or Gpp(NH)p (Fig. 3), and of $5 \mathrm{mmol} / 1 \mathrm{NaF}$ (Table 1 ). Apart from a relatively poor stimulatory effect of $\mathrm{PGE}_{1}$ on $\mathrm{Gpp}(\mathrm{NH}) \mathrm{p}$ activation of adenylate cyclase in obese mice (Fig. 3), there was no obvious difference between the responses of lean and obese animals. Thomas and Stock [26] have reported that $\mathrm{PGE}_{1}$, in the presence of a guanyl nucleotide, stimulates adenylate cyclase in purified plasma membranes from rat adipose tissue. Since $\mathrm{PGE}_{1}$ reduces cyclic AMP elevations elicited by isoproterenol in intact fat cells or adipose tissue fragments [27], they suggested that a component, necessary for the $\mathrm{PGE}_{1}$ inhibition of isoproterenol stimulation in intact fat cells, disappeared during the isolation procedure of plasma membranes [26].

In conclusion, the adenylate cyclase system in the adipose tissue plasma membranes from obesehyperglycaemic mice shows three differences when compared with lean mice: a defect in basal and total activities, an impairment in isoproterenol stimulation and no stimulatory effect of ethanol upon guanyl nucleotide activation. On the other hand, GTP and $\mathrm{Gpp}(\mathrm{NH}) \mathrm{p}$, as well as $\mathrm{PGE}_{1}$, exerted the same effects in both preparations. These data might be explained by a decreased number of catalytic units per mg protein. In addition, the impairment of isoproterenol activation might be due to a defect in the binding of the hormone, and/or to an alteration in the coupling between the hormone receptor and the catalytic unit. Our results with ethanol suggest that the transducing process operated in a different lipid environment.

Acknowledgements. J. P. Dehaye is Aspirant of Fonds National de la Recherche Scientifique (Belgium). This work was supported by Grant $n^{\circ} 20403$ from the Fonds de la Recherche Scientifique Médicale (Belgium). The authors are indebted to Mrs. J. Ballinckx for editing the manuscript.

\section{References}

1. Siddle, K., Hales, C. N.: Hormonal control of adipose tissue lipolysis. Proc. Nutr. Soc. 34, 233-239 (1975)

2. Steinberg, D., Huttunen, J. K.: The role of cyclic AMP in activation of hormone sensitive lipase of adipose tissue. Adv. Cyclic Nucleotide Res. 1, 47-62 (1972)

3. Marshall, N. B., Engel, F. L.: The influence of epinephrine and fasting on adipose tissue content and release of free fatty acids in obesehyperglycaemic and lean mice. J. Lipid Res. 1, 339-342 (1960)

4. Steinmetz, J., Lowry, L., Yen, T. T. T.: An analysis of the lipolysis in vitro of obese-hyperglycaemic and diabetic mice. Diabetologia 5, 373-378 (1969)

5. Dehaye, J. P., Winand, J., Christophe, J.: Lipolysis and cyclic AMP levels in epididymal adipose tissue of obese-hyperglycaemic mice. Diabetologia 13, 553-561 (1977)

6. Enser, M.: Fatty acid mobilization in obese mice. Nature 226, 175-177 (1970)

7. Laudat, M. H., Combret, Y., Laudat, P.: Activité adénylcyclasique membranaire du tissu adipeux de la souris obèse hyperglycémique de Bar-Harbor. C. R. Acad. Sci. [D] (Paris) 276, 407-409 (1973)

8. Laudat, M. H., Pairault, J.: An impaired response of adenylate cyclase to stimulation by epinephrine in adipocyte plasma membrane from genetically obese mice (ob/ob). Eur. J. Biochem. 56, 583-589 (1975)

9. Dehaye, J., Winand, J., Christophe, J.: Regulation of adenylate cyclase activity in the $25,000 \times$ g sediment of adipose tissue from obese-hyperglycemic (ob/ob) mice from Bar Harbor. Arch. Int. Physiol. Biochem. 84, 154-156 (1976)

10. Salomon, Y., Londos, C., Rodbell, M.: A highly sensitive adenylate cyclase assay. Anal. Biochem. 58, 541-548 (1974)

11. Lowry, O. H., Rosebrough, N. J., Farr, A. L., Randall, R. J.: Protein measurement with the Folin phenol reagent. J. Biol. Chem. 193, 265-275 (1951)

12. Christophe, J., Dagenais, Y., Mayer, J.: Increased circulating insulin-like activity in obese-hyperglycaemic mice. Nature 184, 61-62 (1959)

13. Soll, A. H., Kahn, C. R., Neville, D. M., Jr.: Insulin binding to liver plasma membranes in the obese hyperglycemic (ob/ob) mouse. Demonstration of a decreased number of functionally normal receptors. J. Biol. Chem. 250, 4702-4707 (1975)

14. Chang, K. J., Huang, D., Cuatrecasas, P.: The defect in insulin receptors in obese-hyperglycaemic mice: a probable accompaniment of more generalized alterations in membrane glycoproteins. Biochem. Biophys. Res. Commun. 64, 566-573 (1975)

15. Laudat, M. H., Pairault, J., Bayer, P., Martin, M., Laudat, P.: Preparation of fat cell membrane with high sensitivity to lipolytic hormones. Biochim. Biophys. Acta 255, 1005-1008 (1972) 
16. Abraham, R. R., Beloff-Chain, A.: Hormonal control of intermediary metabolism in obese hyperglycemic mice. I. The sensitivity and response to insulin in adipose tissue and muscle in vitro. Diabetes 20, 522-534 (1971)

17. Robison, G. A., Butcher, R.W., Sutherland, E.W.: Adenyl cyclase as an adrenergic receptor. Ann. N. Y. Acad. Sci. 139, 703-723 (1967)

18. Birnbaumer, L., Pohl, S. L., Rodbell, M.: Adenyl cyclase in fat cells. 1 . Properties and the effects of adrenocorticotropin and fluoride. J. Biol. Chem. 244, 3468-3476 (1969)

19. Hepp, K. D.: Studies on the mechanism of insulin action: basic concepts and clinical implications. Diabetologia 13, 177-186 (1977)

20. Laudat, P., Laudat, M.H., Freychet, P.: Insulin and epinephrine interactions with the fat cell plasma membrane in the obese hyperglycemic mouse. Excerpta Medica (Amst.) Intern. Congress Series 280, 75 (1973)

21. Rodbell, M., Birnbaumer, L., Pohl, S. L., Krans, H. M. J.: The glucagon-sensitive adenyl cyclase system in plasma membranes of rat liver. J. Biol. Chem. 246, 1877-1882 (1971)

22. Cooper, B., Partilla, J. S., Gregerman, R. I.: Human fat cell adenylate cyclase. Enzyme characterization and guanine nucleotide effects on epinephrine responsiveness in cell membranes. Biochim. Biophys. Acta 445, 246-258 (1976)

23. Yount, R. G., Babcock, D., Ballantyne, W., Ojala, D.: Adenylyl imidodiphosphate, an adenosine triphosphate analog containing a P-N-P linkage. Biochemistry 10, 2484-2489 (1971)

24. Gorman, R. E., Bitensky, M. W.: Selective activation by short chain alcohols of glucagon responsive adenyl cyclase in liver. Endocrinology 87, 1075-1081 (1970)

25. Levey, G. S., Fletcher, M. A., Klein, I., Ruiz, E., Schenk, A.: Characterization of ${ }^{125} \mathrm{I}$-glucagon binding in a solubilized preparation of cat myocardial adenylate cyclase. Further evidence for a dissociable receptor site. J. Biol. Chem. 249, 2665-2673 (1973)

26. Thomas, T., Stock, K.: Differential effects of prostaglandin $\mathrm{E}$ and phenylisopropyl-adenosine on cAMP accumulation in intact adipocytes of rats and adenyl cyclase activity of adipocyte plasma membranes. Naunyn Schmiedebergs Arch. Pharmacol. 287, R47 (1975)

27. Butcher, R.W., Baird, C. E.: Effects of prostaglandins on adenosine $3^{\prime}, 5^{\prime}$-monophosphate levels in fat and other tissues. J. Biol. Chem, 243, 1713-1717 (1968)

Received: September 9, 1977,

and in revised form: February 8, 1978

Dr. J. Christophe

Laboratoire de Chimie biologique

et de la Nutrition

Faculté de Médecine

Université libre de Bruxelles

rue Evers, 2

B-1000 Bruxelles

Belgium 